\title{
CONTROLLED-RELEASE FERTILIZER IN THE GROWTH OF Dalbergia nigra SEEDLINGS
}

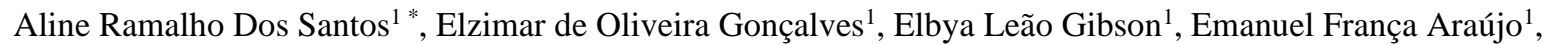 \\ Marcos Vinicius Winckler Caldeira ${ }^{1}$ \\ ${ }^{1}$ Federal University of Espírito Santo, Department of Forest and Wood Sciences, Jerônimo Monteiro, Espírito Santo, Brazil - \\ alineramalho13@hotmail.com*, elzimar.goncalves@ufes.br, elbyagibson@hotmail.com, emanuelfa.bj@hotmail.com, \\ mvwcaldeira@gmail.com
}

Received for publication: 10/04/2018 - Accepted for publication: 22/04/2019

\begin{abstract}
Resumo
Fertilizante de liberação controlada no crescimento de mudas de Dalbergia nigra. Para a viabilização de projetos de restauração florestal é fundamental a produção de mudas florestais nativas em quantidade, necessário também que as mesmas apresentem maior vigor vegetativo e bom estado nutricional. Neste contexto, o objetivo do trabalho foi analisar o crescimento e a nutrição de fósforo de mudas de Dalbergia nigra de duas procedências cultivadas com doses de fertilizante de liberação controlada (FLC). O delineamento experimental foi em blocos casualizados, disposto em esquema fatorial $2 \times 4$, referentes a lotes de duas procedências de sementes de $D$. nigra (Viçosa, MG e Linhares, ES) e quatro doses de FLC $\left(0 ; 2 ; 4\right.$ e $8 \mathrm{~kg} \mathrm{~m}^{-3}$ ), com quatro repetições e 126 mudas por parcela. Aos 60, 90 e 120 dias após semeadura, as mudas foram coletadas para mensuração das variáveis relacionadas ao crescimento e nutrição. As mudas de D. nigra procedentes de Linhares (ES) apresentam melhores resultados de crescimento e produção de massa seca. Recomenda-se dose $7,46 \mathrm{~kg} \mathrm{~m}^{-3} \mathrm{de}$ fertilizante de liberação controlada para as mudas procedentes de Linhares (ES) e a dose $5,99 \mathrm{~kg} \mathrm{~m}^{-3}$ para as procedentes de Viçosa (MG), visando a maximização do crescimento de produção de mudas de D. nigra. As doses crescentes de fertilizante de liberação controlada permitem maior acúmulo de $\mathrm{P}$ na parte aérea de mudas de D. nigra.

Palavras-chave: jacarandá-da-bahia, propagação de plantas, silvicultura, nutrição florestal.
\end{abstract}

\begin{abstract}
For the realization of forest restoration projects, it is essential to produce native seedlings in quantity, also necessary that they present greater vegetative vigor and good nutritional status. In this context, the objective of this work was to analyze the growth and nutrition of phosphorus of Dalbergia nigra seedlings from two sources cultivated with doses of controlled-release fertilizer (CRF). The experimental design was in randomized blocks, arranged in a factorial scheme $2 \times 4$, referring to lots of two seed sources of D. nigra (Viçosa, MG and Linhares, ES) and four doses of CRF (0, 2, 4 and $\left.8 \mathrm{~kg} \mathrm{~m}^{-3}\right)$, with four replications and 126 seedlings per plot. At 60,90 and 120 days after sowing, the seedlings were collected to measure the variables related to growth and nutrition. D. nigra seedlings from Linhares (ES) show better growth and dry matter production. It is recommended to dose $7.46 \mathrm{~kg} \mathrm{~m}^{-3}$ of controlled-release fertilizer for seedlings from Linhares (ES) and the dose $5.99 \mathrm{~kg} \mathrm{~m}^{-3}$ for those coming from Viçosa (MG), aiming to maximize the growth of production of seedlings of D. nigra. Increasing doses of controlled-release fertilizer allow greater accumulation of $\mathrm{P}$ in shoot shoots of $\mathrm{D}$. nigra. Keywords: jacarandá-da-bahia, plant propagation, forestry, forest nutrition.
\end{abstract}

\section{INTRODUCTION}

Brazil made international commitments to reduce climate change in the Paris Agreement, signed in 2015. For this purpose, it committed itself to reforest and promote the regeneration of 12 million hectares by 2030 (BRASIL, 2018). The use of seedlings of native species in plantations is to overcome the difficulties of aggravating problems of fragmentation and environmental degradation. Most producers of native seedlings use standard substrate composed of subsurface soil samples and a source of organic matter, a practice that is gradually being replaced by commercial substrates (SENA et al., 2010). According to Serrano et al. (2012), it is characteristic of commercial substrates the dependence on mineral fertilizer applications through frequent foliar spraying, covering or fertigation, which can result in increased production costs.

Controlled-release fertilizers (CRF) are polymer-coated fertilizers, deliberately made to release the active nutrient in a controlled manner, prolonging the duration of nutrient release and in sync with the plant's metabolic needs (ROSSA et al., 2015). CRFs have been researched to have the optimal release of nutrients so that the rate of release of nutrients corresponds to the maximum rate of absorption of nutrients by plants, which varies dynamically during the stages of plant development during the growing season (IRFAN et al., 2018). For the

FLORESTA, Curitiba, PR, v. 50, n. 2, p. 1203 - 1212, abr/jun 2020.

Santos, A. R. et.al.

ISSN eletrônico 1982-4688

DOI: $10.5380 /$ rf.v50 i2. 62080 
production of Moringa oleifera seedlings, Rosa et al. (2018) found improvement in seedling growth when they used the controlled-release fertilizer at a dose of $5.37 \mathrm{~kg} / \mathrm{m}^{-3}$ of substrate.

Jacarandá caviúna or jacarandá-da-bahia are popular names of Dalbergia nigra (Vell.) Allemão ex Benth, an arboreal Fabaceae, endemic to the Atlantic Forest (CARVALHO, 2003). Due to the natural beauty and technological properties of its wood, it was the target of intense extractive exploitation, which, added to the degradation of its natural environment, resulted in populations reduced to isolated forest fragments and conservation units (CARVALHO, 2003). Consequently, it is currently listed as an endangered species and its international trade is prohibited (RESENDE et al., 2011).

Obtaining improved populations that meet the requirements of forest productivity, or environmental recovery, depends on the ability to identify desired genotypes in the population under this selection. According to Zaruma et al. (2015), one of the proven efficiency strategies for genotype selection is the combination of provenance and progeny tests. Variability between populations has always been the subject of studies in different species, taking into consideration knowing and exploring this variability in breeding and genetic conservation programs. Based on this, populations of different geographic origins may present genetic differences that emerged from adaptation to the local environmental conditions in which they live (OHASHI et al., 2010).

For this purpose, the hypothesis that the CRF doses exert an influence on the growth of $D$. nigra seedlings was tested, with the aim of this study to analyze the growth and phosphorus nutrition of $D$. nigra seedlings from two sources. grown with CRF doses.

\section{MATERIAL AND METHODS}

The experiment was installed and conducted in the university forest nursery located in the experimental area of the Department of Forest and Wood Sciences belonging to the Federal University of Espírito Santo (DCFMCCA-UFES), in Jerônimo Monteiro, ES, during the months of August 2017 to November 2017. The experimental area has a latitude of $20^{\circ} 47$ 'S and a longitude of $41^{\circ} 23^{\prime} \mathrm{W}$ and an altitude of $120 \mathrm{~m}$. The region's climate is classified by Köppen (1948) as being of the Cwa type (dry winter and rainy summer), with an average annual temperature of $24.1^{\circ} \mathrm{C}$. The average annual precipitation is $1,104 \mathrm{~mm}$ (LIMA et al., 2008).

The seeds of D. nigra were purchased in the municipality of Viçosa, in Minas Gerais, Brazil, and in Linhares, in Espírito Santo (Brazil), through marketing carried out by companies registered with the Ministry of Agriculture, Livestock and Supply (MAPA).

The experimental design used was in randomized blocks, in a $2 \times 4$ factorial scheme, with four replications, and two origins of D. nigra (Viçosa, MG and Linhares, ES) were studied in response to four doses of CRF Basacote® Mini 6M: 0 (control); 2.0; 4.0 and $8.0 \mathrm{~kg} \mathrm{~m}^{-3}$, whose formulation is 13-6-16, with a release time of 5 to 6 months. Table 1 shows the chemical-physical characterization of the CRF. Each experimental unit consisted of 126 seedlings, totaling 4,032 seedlings.

Table 1. Chemical-physical characterization of controlled-release fertilizer

Tabela 1. Caracterização químico-física do fertilizante de liberação controlada

\begin{tabular}{ccccccccccc}
\hline $\mathrm{N}$ & $\mathrm{P}_{2} \mathrm{O}_{5}$ & $\mathrm{~K}_{2} \mathrm{O}$ & $\mathrm{Mg}$ & $\mathrm{S}$ & $\mathrm{Fe}$ & $\mathrm{Cu}$ & $\mathrm{Mn}$ & $\mathrm{No}$ & $\begin{array}{c}\text { Granules } \\
\text { diameter }\end{array}$ & $\begin{array}{c}\text { Weight of } \\
1,000 \text { grains }\end{array}$ \\
\hline-13.00 & 6.00 & 16.00 & 1.40 & 10.00 & 0.26 & 0.05 & 0.06 & 0.015 & $1.5 / 2.5$ & 9.58 \\
\hline
\end{tabular}

Source: Compo expert

The different doses of CRF were added to the commercial substrate composed of: Pinus bark, vermiculite, agro-industrial organic waste class A, wood sawdust, horse bed manure and NPK, with a pH of 6.2, density of 0 . $5 \mathrm{~g} \mathrm{~cm}^{-3}$, humidity of $55 \%$, electrical conductivity $0.4 \mathrm{mS} \mathrm{cm}{ }^{-1}$ (BIOMIX). The materials were homogenized manually with the aid of hoes, before filling the tubes. Sowing was carried out at $0.3 \mathrm{~cm}$ deep in $280 \mathrm{~cm}^{3}$ polypropylene tubes, with external dimensions of $64.5 \mathrm{~mm}$, internal dimensions of $52 \mathrm{~mm}$ and height of $190 \mathrm{~mm}$, in a shade house with a $50 \%$ reduction in luminous intensity. Each tube received three seeds, previously disinfected in $70 \%$ alcohol under agitation for one minute and sodium hypochlorite solution (2\%) for three minutes, followed by a triple wash in distilled water (DUTRA et al., 2016). At 15 days after emergence, a first thinning was carried out, leaving two plants per tube. After 30 days after sowing, a second thinning was carried out, leaving only one seedling per tube. 
The emergence percentage (E), calculated by the equation proposed in the Rules for Seed Analysis (BRASIL, 2009), the emergence speed index (ESI) and the mean emergence time (MET) were analyzed. Emerged seedlings with cotyledons above the substrate were considered normal seedlings.

At 60, 90 and 120 days after emergence, the following variables were determined: the height of the aerial part $(\mathrm{H})$ assessed from the seedling neck until the insertion of the last leaf, with the aid of a graduated ruler; diameter at root collar (DRC), measured at the level of the tube edge using a digital caliper; number of leaves (NL), determined by counting the number of visible leaves; leaf chlorophyll content (LCC), carried out on samples of intermediate leaves of the seedlings by means of a portable chlorophyll meter SPAD-502. The determination of CRF was performed only at doses $2.0 ; 4.0$ and $8.0 \mathrm{~kg} \mathrm{~m}^{-3}$, since the low leaf growth of the 0.0 treatment seedlings did not allow reading with the mentioned device.

Four seedlings per repetition were collected at random and sectioned for evaluation. The root system was separated from the soil by washing with running water and the length of the main root (RL) was evaluated. Then, the material was packed in kraft paper bags and placed to dry in an oven with forced air circulation at a temperature of $65{ }^{\circ} \mathrm{C}$ until constant weight, being then weighed on an analytical balance (with precision of $0.0001 \mathrm{~g}$ ) for determination dry matter of the aerial part (DMAP) and root dry matter (RDM), with the sum of the two composing the total dry mass (TDM). After obtaining these variables, the Díckson Quality Index (DQI) was determined.

After drying in an oven, the dry mass of the plants was ground in a stainless steel Willey® mill and sieved in a 20 mesh sieve to determine the nutritional contents of phosphorus $\left(\mathrm{P}, \mathrm{g} \mathrm{kg}^{-1}\right)$, by means of nitro digestion. These levels were analyzed by spectrophotometry according to the methodology described in Silva (2009). The accumulation of $\mathrm{P}$ in the aerial part (APAP) was obtained by multiplying the P content and the DMAP.

The data were submitted to the assumption of normality verification test (Shapiro-Wilk). The variables $\mathrm{E}$ (\%), DRC (120 days), H (120 days), NL (120 days), RL, DRM, DMAP, TDM, DQI and APAP presented the pvalue results below 0.05 , not having their normal waste distributions, which led to the transformation of the data using the function $Y=$ root $(x+1)$, however, presented in the original version. Then the data were subjected to analysis of variance and when checking for significant differences, by the $\mathrm{F}$ test at $5 \%$, the two provenances were compared by the Tukey test at the level of $5 \%$ probability and the doses to the regression analysis using the first derived from the estimators $\beta 0$ and $\beta 1$. For the choice of equations, the significance of the parameters, $t$ test, the biological significance and realism of the models (linear and quadratic) and the determination coefficient $\left(\mathrm{R}^{2}\right)$ were considered. The analyzes were performed using the SISVAR 5,4 program (Ferreira, 2014).

\section{RESULTS}

According to the results in the analysis of variance (Table 2), it appears that there was an interaction ( $\mathrm{p} \leq$ 0.05) between the factors CRF doses and origins of D. nigra for the variables height at 120 days, root dry mass, dry mass of the aerial part and total dry mass, showing that the joint action of the factors influenced the expression of these characteristics. The CRF doses influenced all the variables studied, with the exception of the mean emergency time. The seeds from Linhares (ES) showed higher values of emergency speed, emergency and Dickson quality index, while those from Viçosa (MG) had a shorter average emergence time, number of leaves and accumulation of phosphorus in the aerial part.

Table 2. Analysis of variance and test of means of the growth variables of two origins of $D$. nigra submitted to different doses of controlled-release fertilizers.

Tabela 2. Análise de variância e teste de médias das variáveis de crescimento de duas procedências de $D$. nigra submetidas a diferentes doses de fertilizantes de liberação controlada.

\begin{tabular}{|c|c|c|c|c|c|c|c|}
\hline \multirow[t]{2}{*}{ SV } & \multirow[t]{2}{*}{$\mathrm{DF}$} & \multicolumn{6}{|c|}{ Mean squares } \\
\hline & & $\begin{array}{l}\mathrm{E} \\
(\%)\end{array}$ & $\begin{array}{c}\text { ESI } \\
\text { (days) }\end{array}$ & $\begin{array}{l}\text { MET } \\
\text { (days) }\end{array}$ & $\begin{array}{l}\text { DRC } 60 \\
(\mathrm{~mm})\end{array}$ & $\begin{array}{l}\text { H } 60 \\
(\mathrm{~mm})\end{array}$ & $\begin{array}{l}\text { NL 60 } \\
\text { (unit) }\end{array}$ \\
\hline Doses (D) & 3 & $2.546^{*}$ & $2.125^{* *}$ & $0.303^{\mathrm{ns}}$ & $0.262 * *$ & $27.661 * *$ & $19.70 * *$ \\
\hline Origin $(\mathrm{O})$ & 1 & $11.970 * *$ & $5.104 * *$ & $29.376^{* *}$ & $0.039^{\mathrm{ns}}$ & $5.925^{\mathrm{ns}}$ & $1.757^{\mathrm{ns}}$ \\
\hline $\mathrm{D} \times \mathrm{O}$ & 3 & $0.489^{\mathrm{ns}}$ & $0.360^{\mathrm{ns}}$ & $0.258^{\mathrm{ns}}$ & $0.015^{\mathrm{ns}}$ & $0.695^{\mathrm{ns}}$ & $1.825^{\mathrm{ns}}$ \\
\hline Block & 3 & $0.281^{\mathrm{ns}}$ & $0.189^{\mathrm{ns}}$ & $0.349^{\mathrm{ns}}$ & $0.057^{\mathrm{ns}}$ & $0.897^{\mathrm{ns}}$ & $2.341^{\mathrm{ns}}$ \\
\hline Waste & 21 & 0.586 & 0.429 & 0.331 & 0,028 & 1.96 & 1.678 \\
\hline $\mathrm{CV} \%$ & & 11.99 & 22.90 & 3.12 & 14,87 & 28.44 & 24.04 \\
\hline Average ES & & $48.90 \mathrm{a}$ & $3.26 \mathrm{a}$ & $19.41 \mathrm{~b}$ & $3.26 \mathrm{a}$ & $3.26 \mathrm{a}$ & $3.26 \mathrm{a}$ \\
\hline Average MG & & $32.88 \mathrm{~b}$ & $3.26 \mathrm{a}$ & $48.90 \mathrm{a}$ & $3.26 \mathrm{a}$ & $3.26 \mathrm{a}$ & $3.26 \mathrm{a}$ \\
\hline
\end{tabular}

FLORESTA, Curitiba, PR, v. 50, n. 2, p. 1203 - 1212, abr/jun 2020. 


\begin{tabular}{|c|c|c|c|c|c|c|c|}
\hline \multirow[t]{2}{*}{$\mathrm{SV}$} & \multirow[t]{2}{*}{$\mathrm{DF}$} & \multicolumn{6}{|c|}{ Mean squares } \\
\hline & & $\begin{array}{l}\begin{array}{l}\text { DRC 90 } \\
(\mathrm{mm})\end{array} \\
\end{array}$ & $\begin{array}{l}\text { H 90 } \\
(\mathrm{mm})\end{array}$ & $\begin{array}{l}\text { NL 90 } \\
\text { (unit) }\end{array}$ & $\begin{array}{l}\text { DRC } 120 \\
(\mathrm{~mm})\end{array}$ & $\begin{array}{l}\text { H } 120 \\
(\mathrm{~mm})\end{array}$ & $\begin{array}{l}\text { NL 120 } \\
\text { (unit) }\end{array}$ \\
\hline Doses (D) & 3 & $3.193 * *$ & $511.52 * *$ & $355.18 * *$ & $1.086^{* *}$ & $27.44 * *$ & $24.294 * *$ \\
\hline Origin $(\mathrm{O})$ & 1 & $0.241^{\mathrm{ns}}$ & $29.10^{\text {ns }}$ & $0.236^{\mathrm{ns}}$ & 0.022 ns & 0.35 ns & $1,081 *$ \\
\hline $\mathrm{D} \times \mathrm{O}$ & 3 & $0.124^{\text {ns }}$ & 28.62 ns & $2.116^{\mathrm{ns}}$ & $0.027^{\mathrm{ns}}$ & $1.22 * *$ & $0.088^{\mathrm{ns}}$ \\
\hline Block & 3 & $0.186^{\mathrm{ns}}$ & $18.44^{\mathrm{ns}}$ & $6.054^{\mathrm{ns}}$ & $0.027^{\text {ns }}$ & $0.57^{\mathrm{ns}}$ & $0.554^{\mathrm{ns}}$ \\
\hline Waste & 21 & 0.113 & 14.07 & 14.12 & 0.010 & 0.19 & 0.177 \\
\hline CV\% & & 17.96 & 27.57 & 28.05 & 5.20 & 9.45 & 9.15 \\
\hline Average ES & & $1.96 \mathrm{a}$ & $14.56 \mathrm{a}$ & $13.31 \mathrm{a}$ & $3.09 \mathrm{a}$ & $25.05 \mathrm{a}$ & $20.93 \mathrm{~b}$ \\
\hline Average MG & & $1.78 \mathrm{a}$ & $12.65 \mathrm{a}$ & $13.48 \mathrm{a}$ & $2.85 \mathrm{a}$ & $21.58 \mathrm{a}$ & $24.41 \mathrm{a}$ \\
\hline \multirow[t]{2}{*}{$\mathrm{SV}$} & $\overline{D F}$ & \multicolumn{6}{|c|}{ Mean squares } \\
\hline & & $\begin{array}{l}\mathrm{RL} \\
(\mathrm{cm})\end{array}$ & $\begin{array}{l}\text { RDM } \\
(\mathrm{g})\end{array}$ & $\begin{array}{l}\text { DMAP } \\
(\mathrm{g})\end{array}$ & $\begin{array}{l}\text { TDM } \\
(\mathrm{g})\end{array}$ & $\overline{\mathrm{DQI}}$ & $\begin{array}{l}\text { APAP } \\
(\mathrm{mg})\end{array}$ \\
\hline Doses (D) & 3 & $0.312 * *$ & $0.303^{* *}$ & $0.907 * *$ & $1.663 * *$ & $0.123 * *$ & $7.614 * *$ \\
\hline Origin $(\mathrm{O})$ & 1 & $0.073^{\text {ns }}$ & $0.039^{* *}$ & $0.037^{*}$ & $0.097^{*}$ & $0.008^{*}$ & $0.130^{\mathrm{ns}}$ \\
\hline $\mathrm{D} \times \mathrm{O}$ & 3 & $0.006^{\mathrm{ns}}$ & $0.016^{*}$ & $0.029 *$ & $0.057^{*}$ & $0.003^{\mathrm{ns}}$ & $0.072^{\mathrm{ns}}$ \\
\hline Block & 3 & $0.175^{\mathrm{ns}}$ & $0.006^{\mathrm{ns}}$ & $0.023^{\mathrm{ns}}$ & $0.035^{\mathrm{ns}}$ & $0.004^{\mathrm{ns}}$ & $0.289^{\mathrm{ns}}$ \\
\hline Waste & 21 & 0.030 & 0.003 & 0.007 & 0.013 & 0.001 & 0.0910 \\
\hline $\mathrm{CV} \%$ & & 3.75 & 4.53 & 6.17 & 7.19 & 24.68 & 12.36 \\
\hline Average ES & & $21.23 \mathrm{a}$ & $0.75 \mathrm{a}$ & $1.20 \mathrm{a}$ & $1.96 \mathrm{a}$ & $0.19 \mathrm{a}$ & $5.34 \mathrm{a}$ \\
\hline Average MG & & $20.33 \mathrm{a}$ & $0.55 \mathrm{a}$ & $0.96 \mathrm{a}$ & $1.52 \mathrm{a}$ & $0.15 \mathrm{a}$ & $6.19 \mathrm{a}$ \\
\hline
\end{tabular}

SV: source of variation; DF: degrees of freedom; CV\%: coefficient of variation; E: emergency; ESI: emergency speed index; AET: average emergency time; DRC 60: diameter at root collar 60 days after sowing; H 60: seedling height 60 days after sowing; NL 60: number of leaves 60 days after sowing; DRC 90: diameter root collar 90 days after sowing; H 90: seedling height 90 days after sowing; NL 90: number of leaves 90 days after sowing; DRC 120: diameter at root collar 120 days after sowing; H 120: seedling height 120 days after sowing; NL 120: number of leaves 120 days after sowing; RL: root length; DRM: dry root mass; DMAP: dry mass of the aerial part; TDM: total dry mass; DQI: Dickson's

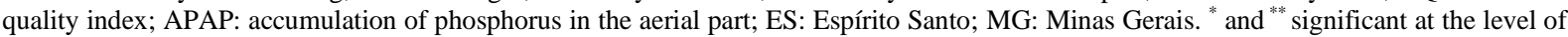
$5 \%$ and $1 \%$ probability by the $\mathrm{F}$ test respectively; ${ }^{\mathrm{ns}}$ not significant at $5 \%$ probability, by the $\mathrm{F}$ test.

The CRF doses influenced $(p \leq 0.05)$ negatively the emergence and the emergence speed index. The lower emergency results $(33.58 \%)$ were found in the dose of $5.03 \mathrm{~kg} \mathrm{~m}^{-3}$. For the emergency speed index, the minimum estimated value (2.35) occurred at the dose of $5.12 \mathrm{~kg} \mathrm{~m}^{-3}$, both variables represented by negative quadratic regression, with the best results observed at the dose $0 \mathrm{~kg} \mathrm{~m}^{-3}$ (Figure 1A, 1B).
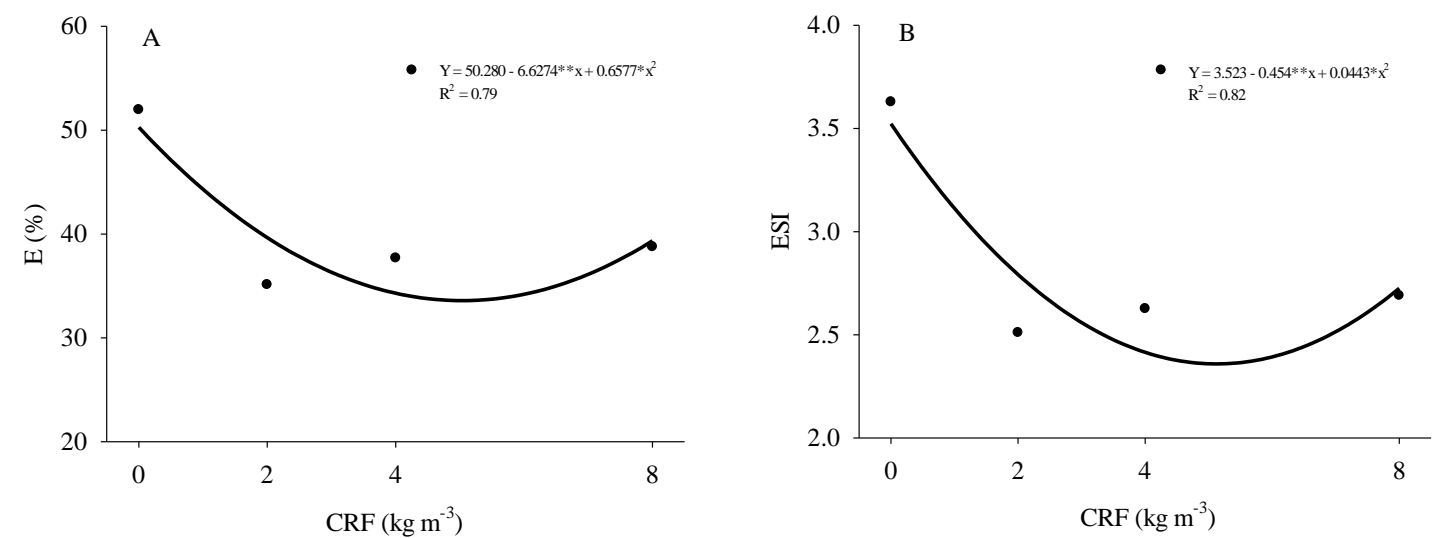

Figure 1. (A) Percentage of emergency; (B) seedling emergence speed index of D. nigra as a function of doses of controlled-release fertilizers, Jerônimo Monteiro, Brazil, 2018.

Figura 1. (A) Porcentagem de emergência; (B) índice de velocidade de emergência de plântulas de D. nigra em função de doses de fertilizante de liberação controlada, Jerônimo Monteiro, Brasil, 2018. 
The maximum height of $6.77 \mathrm{~cm}$ plant ${ }^{-1}$ at 60 days was observed in the estimated dose of $5.83 \mathrm{~kg} \mathrm{~m}^{-3}$ (Figure 2A). The greatest growth in diameter at root collar at 60 days was $1.33 \mathrm{~mm}$ plant $^{-1}$ in the dose $5.29 \mathrm{~kg} \mathrm{~m}^{-}$ 3 (Figure 2B).
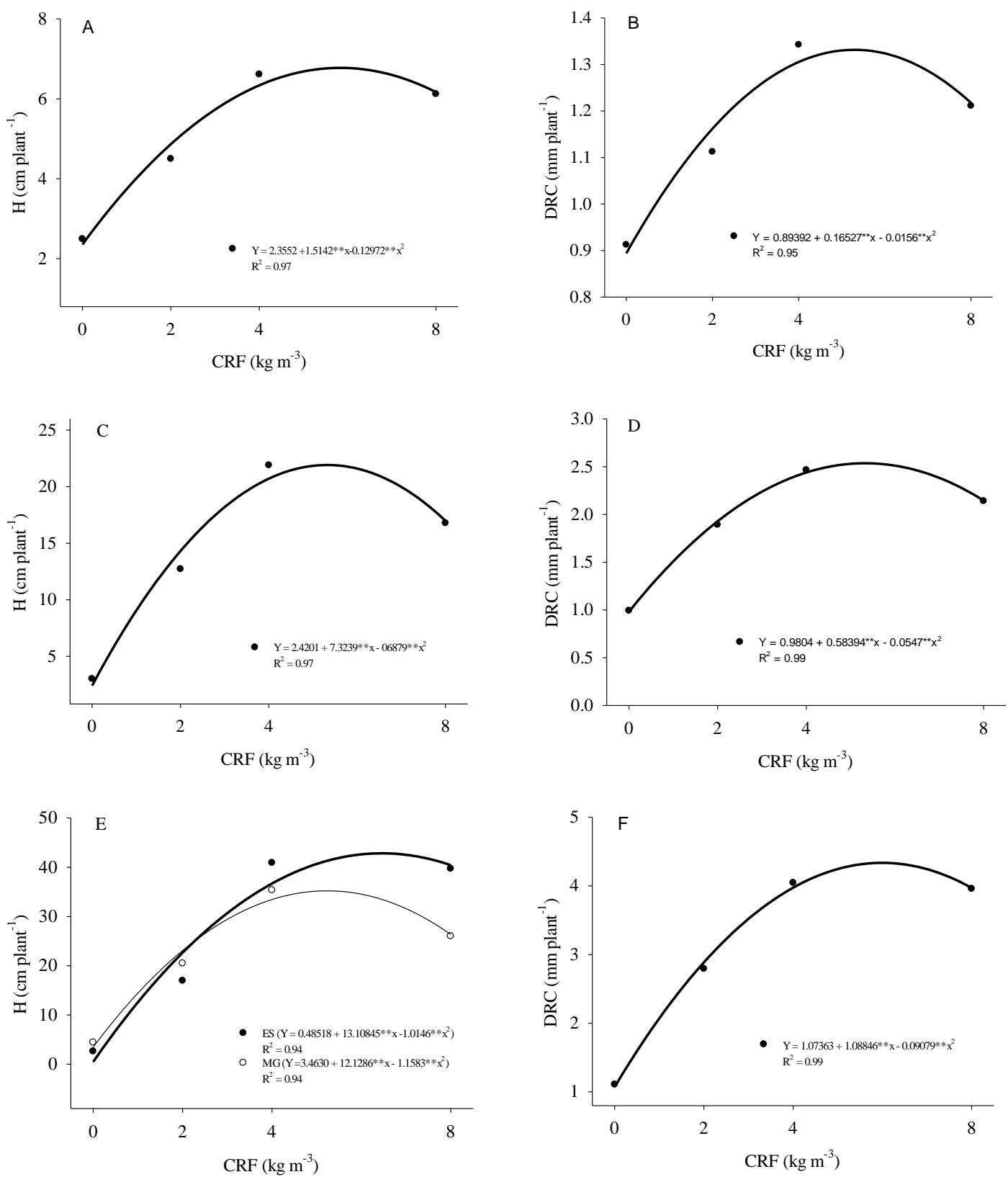

Figure 2. (A) Height at 60 days; (B) diameter at root collar at 60 days; (C) Height at 90 days; (D) diameter at root collar at 90 days; (E) Height at 120 days; (F) diameter at root collar at 120 days of seedlings of D. nigra as a function of controlled fertilizer doses, Jerônimo Monteiro, Brazil, 2018.

Figura 2. (A) Altura aos 60 dias; (B) diâmetro do coleto aos 60 dias; (C) Altura aos 90 dias; (D) diâmetro do coleto aos 90 dias; (E) Altura aos 120 dias; (F) diâmetro do coleto aos 120 dias de plântulas de D. nigra em função de doses de fertilizante de liberação controlada, Jerônimo Monteiro, Brasil, 2018.

The maximum height of $21.91 \mathrm{~cm}$ plant $^{-1}$ at 60 days was observed in the estimated dose of $5.32 \mathrm{~kg} \mathrm{~m}^{-3}$ (Figure 2C). The greatest growth in diameter at root collar at 90 days was $2.53 \mathrm{~mm}^{-1 a n t^{-1}}$ in the dose $5.32 \mathrm{~kg} \mathrm{~m}^{-}$ ${ }^{3}$ (Figure 2D).

There was an interaction between the CRF dose factors and the provenances, where the maximum height at 120 days was $42.82 \mathrm{~cm}$ plant $^{-1}$ for seedlings from Linhares (ES), being observed in the estimated dose $6.45 \mathrm{~kg}$ 
$\mathrm{m}^{-3}$. For those coming from Viçosa (MG), the dose $5.23 \mathrm{~kg} \mathrm{~m}^{-3}$ promoted the highest average height, $35.21 \mathrm{~cm}$ plant $^{-1}$ (Figure 2E). The greatest growth in diameter at root collar at 120 days was $4.33 \mathrm{~mm} \mathrm{plant}^{-1}$ in the dose 5.99 $\mathrm{kg} \mathrm{m}^{-3}$ (Figure 2F).

There was an isolated effect of the CRF doses for the number of leaves in the three evaluation periods, with a quadratic growth trend at 60,90 and 120 days with a maximum value of 7.00; 20.00 and 37.00 leaves in the maximum estimated doses 5.51; 5.74 and $6.44 \mathrm{~kg} \mathrm{~m}^{-3}$ respectively (Figures 3A, 3B, 3C). For the total leaf chlorophyll content at 120 days, the highest value, $40.42 \mathrm{ug} \mathrm{cm}^{-2}$ plant $^{-1}$ was observed at the estimated dose 6.08 $\mathrm{kg} \mathrm{m}^{-3}$ of CRF (Figure 3D).
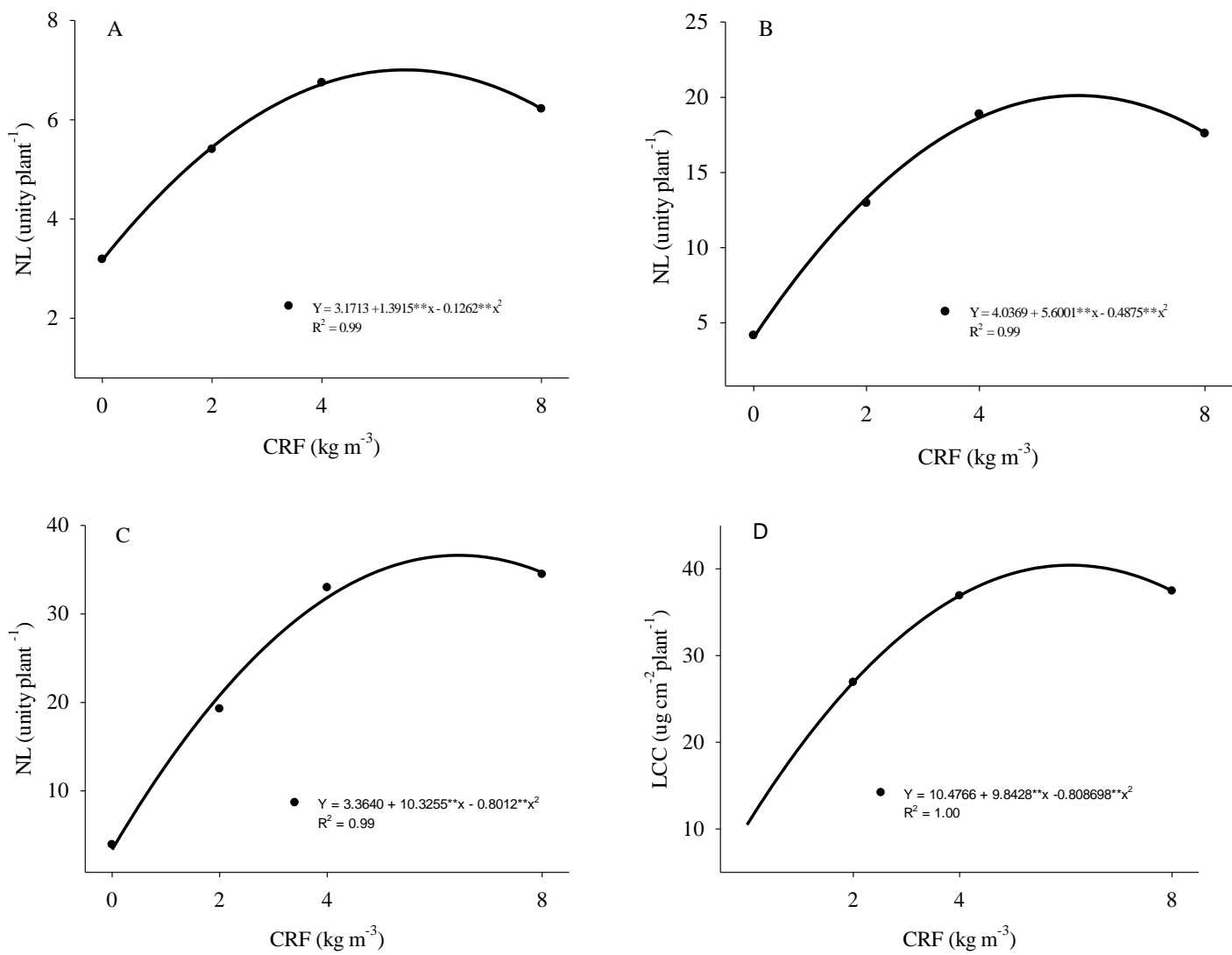

Figure 3. (A) number of leaves at 60 days; (B) number of leaves at 90 days; (C) number of leaves 120 days; (D) total leaf chlorophyll at 120 days of $D$. nigra seedlings as a function doses of controlled-release fertilizers, Jerônimo Monteiro, Brazil, 2018.

Figura 3. (A) número de folhas aos 60 dias; (B) número de folhas aos 90 dias; (C) número de folhas 120 dias; (D) clorofila foliar total aos 120 dias de plântulas de D. nigra em função de doses de fertilizante de liberação controlada, Jerônimo Monteiro, Brasil, 2018.

The CRF doses promoted increasing linear growth of the root system, where the maximum root length $\left(22.75 \mathrm{~cm}\right.$ plant $\left.^{-1}\right)$ was observed in the dose $8 \mathrm{~kg} \mathrm{~m}^{-3}$ (Figure $\left.4 \mathrm{~A}\right)$.

For the dry root mass there was an interaction $(p \leq 0.05)$ between the provenances and CRF doses, in which the D. nigra seedlings from Linhares (ES) had the maximum value of $1.33 \mathrm{~g} \mathrm{plant}^{-1}$ at dose $6.48 \mathrm{~kg} \mathrm{~m}^{-3}$ (Figure 4B). While the seedlings from Viçosa (MG) presented a maximum value of $0.94 \mathrm{~g} \mathrm{plant}^{-1}$ reached in the dose $5.52 \mathrm{~kg} \mathrm{~m}^{-3}$.

As for the dry matter production of the aerial part, there were two growth trends. The highest dry mass production of the aerial part, $2.55 \mathrm{~g} \mathrm{plant}^{-1}$, was observed for seedlings from Linhares (ES) at the dose $8 \mathrm{~kg} \mathrm{~m}^{-3}$, with an increasing linear growth trend. As for those coming from Viçosa (MG), the maximum dry mass production of the aerial part was $1.70 \mathrm{~g} \mathrm{plant}^{-1}$ in the estimated dose of $6.33 \mathrm{~kg} \mathrm{~m}^{-3}$ (Figure 4C).

For the production of total dry mass, the seedlings from Linhares (ES) showed a greater growth, with a maximum value of $3.63 \mathrm{~g}$ plant $^{-1}$ at the dose of $7.46 \mathrm{~kg} \mathrm{~m}^{-3}$ (Figure 4D), while those from Viçosa (MG) showed maximum production in total dry mass of $2.63 \mathrm{~g} \mathrm{plant}^{-1}$ in the estimated CRF dose $5.99 \mathrm{~kg} \mathrm{~m}^{-3}$. 
The maximum Dickson quality index was 0.29 obtained at the estimated dose of $6.71 \mathrm{~kg} \mathrm{~m}^{-3}$ (Figure 4E). The accumulation of phosphorus in the aerial part followed the same trend observed for the root length, where the maximum value of $10.77 \mathrm{mg}_{\text {plant }}{ }^{-1}$ was observed in the dose $8 \mathrm{~kg} \mathrm{~m}^{-3}$, with a linear growth trend increasing (Figure 4F).
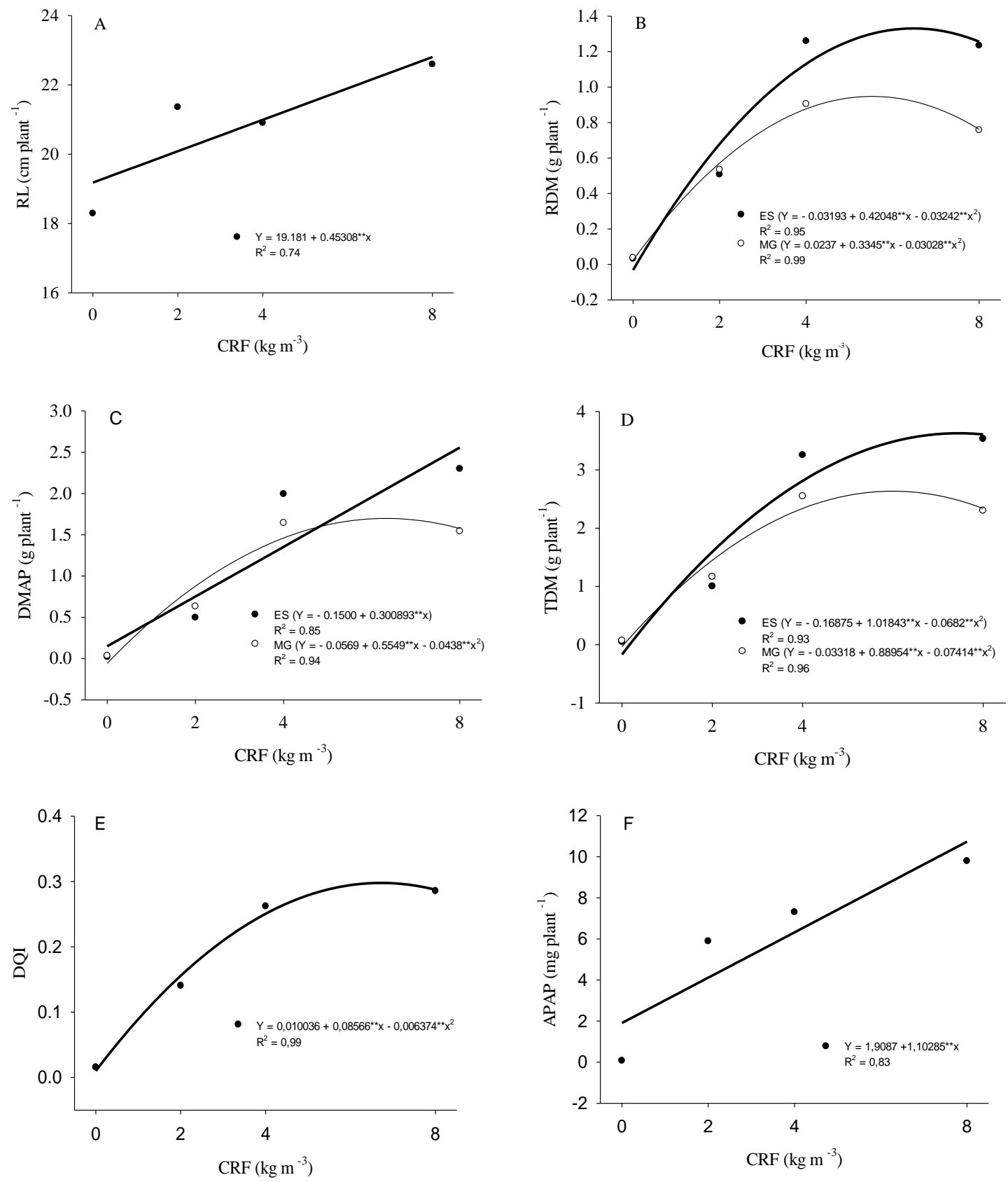

Figure 4. (A) length of the root system; (B) dry root mass; (C) dry mass of the aerial part; (D) total dry mass; (E) Dickson's quality index; (F) accumulation of phosphorus from the aerial part of D. nigra seedlings as a function doses of controlled-release fertilizers, Jerônimo Monteiro, Brazil, 2018.

Figura 4. (A) comprimento do sistema radicular; (B) massa seca da raiz; (C) massa seca da parte aérea; (D) massa seca total; (E) índice de qualidade de Dickson; (F) acúmulo de fósforo da parte aérea de mudas de D. nigra em função de doses de fertilizante controlada, Jerônimo Monteiro, Brasil, 2018. 


\section{DISCUSSION}

Decreases in the emergence values and seedling emergence speed index of D. nigra are observed with the CRF doses, which can be justified by the intrinsic characteristics of the fertilizer, such as hygroscopicity and salinity, which cause the deleterious effect on the seed coat, causing electrolyte leakage (TAVARES et al., 2013). A similar result was found Menegatti et al. (2017) in an experiment carried out with Aspidosperma parvifolium, in which higher doses of CRF provide a reduction in plant growth. Thus, it is suggested to use, when possible, two or more seeds per container to avoid underutilization of tubes and space in the nursery.

In general, the hypothesis that the CRF doses influence the growth of $D$. nigraseedlings is proven, promoting expressive gains in both origins, with emphasis on the variables height, diameter at root collar, total dry mass, with implication in Dickson's quality index. The height and diameter at root collar are non-destructive characteristics, easy to measure, used to evaluate the growth and quality of tree seedlings in the nursery and can be correlated with the survival and growth of seedlings in the field (GOMES; PAIVA, 2011).

The production of dry matter, both root, aerial and total, is considered an important variable to describe the growth and quality of seedlings. According to Larcher (2006), vegetative growth is the result of the difference between carbon gains via photosynthesis and losses via respiration ( $\mathrm{CO}$ balance balance ${ }_{2}$ ), thus, the carbon not consumed in the respiratory process increases the dry mass of the plant. Thus, it is believed that the higher the value of the total dry mass, the better the quality of the seedling produced, the survival and growth of plants after transplanting in the field.

The CRF, anticipated the development of the seedlings and ensured better conditions for the plant to reach its maximum productive potential, both in measurements of aerial parts and those of the root system, making them suitable for transplanting to the field 90 days after emergence, when it had a height of $21.91 \mathrm{~cm} \mathrm{plant}^{-1}$ and diameter of $2.53 \mathrm{~mm}_{\text {plant }}^{-1}$.

From the perspective of recovering degraded areas, quality seedlings, with maximum growth in a nursery, can be established more quickly in the field, covering the soil, creating ideal microclimate conditions for the establishment of other plant species, thus initiating the succession and cycling processes of nutrients. From the standpoint of silvopastoral systems, the faster the initial growth in the field of the forest component, the faster the entry of animals into the area, without prejudice to the quality of the trees.

Although their acquisition cost is elevated in in relation to soluble sources, CRF have been economically viable for use in forest nurseries due to the reduction in final production costs, greater use of the area by decreasing the crop cycle, hand reduction of operations and optimization of space, water and energy (ROSSA et al., 2015).

Gonçalves et al. (2014), when analyzing the effects of mineral fertilization on the growth of seedlings of D. nigra, found at 120 days of sowing, a dry mass production of the aerial part of $2.06 \mathrm{~g} \mathrm{plant}^{-1}$, with the dose of $287.06 \mathrm{mg} \mathrm{dm}^{-3}$, results consistent with those found in this research study.

In general, the literature shows that forest species are very responsive to the addition of CRF to the substrate. Navroski et al. (2016) found that cedar seedlings (Cedrela fissilis) show good growth when $5 \mathrm{~kg} \mathrm{~m}^{-3}$ of $\mathrm{CRF}$ are incorporated into the substrate. For the production of seedlings of Moringa oleifera, Rosa et al. (2018) found improvement in seedling growth when they used the controlled release fertilizer at a dose of $5.37 \mathrm{~kg} \mathrm{~m}^{-3}$ of substrate.

This trend was also observed by Rossa et al. (2015), where it was found that application of CRF leads to significant growth gains of red angico (Anadenanthera peregrina) and red pepper (Schinus terebinthifolius) seedlings, with the best doses being 5.54 to $6,68 \mathrm{~kg} \mathrm{~m}^{-3}$ for the angico-vermelho species and 8.38 to $14.42 \mathrm{~kg} \mathrm{~m}^{-3}$ for aroeira-vermelha. Dutra et al. (2016) concluded that canafistula seedlings (Peltophorum dubium) responded to the use of CRF, presenting better growth and quality standards at doses between 5.4 to $8.2 \mathrm{~g} \mathrm{dm}^{-3}$.

The significant increase in the accumulation of phosphorus in the aerial part of $D$. nigra seedlings as a function of CRF doses is another desirable point in the production of quality seedlings. The presence of this nutrient in the plant stimulates the growth of the root system and promotes the increase of the soil area to be explored, favoring the acquisition of water and nutrients (DIAS et al., 2017). Factor that can be useful in programs for the recovery of degraded areas and commercial plantations, since the survival, establishment and good productivity of forest stands are greater with the robust root system (GOMES; PAIVA, 2011). Carlos et al (2018), aiming to verify the made of phosphorus and limestone doses on the morphological and nutritional characteristics of $D$. nigra seedlings at 240 days, found increasing linear growth, and the dose $500 \mathrm{mg} \mathrm{kg}^{-1}$ of phosphorus promoted an average accumulation of $21.87 \mathrm{mg}$ plant $^{-1}$, showing that the species showed a mechanism of accumulation of phosphorus in the aerial part, possibly being an evolutionary strategy for the growth of the species in soils that present naturally low fertility in regions of the Atlantic Forest.

Interest in growing silvicultural information on tree species in the Brazilian flora is growing, despite the notable advances in the silviculture of native species. Studies are needed to establish optimal nutritional conditions 
for each species grown. It is also observed that the seedlings from Linhares (ES) were more responsive to the addition of CRF in relation to Viçosa (MG) in terms of root, aerial and total dry matter production.

According to Lima et al. (2018), the importance of working with seeds from different locations from a geographical and climatic point of view allows to verify the genetic differences within the species, and the phenotypic differences determined by environmental variations. Knowing the natural variability, individuals or materials that have superior characteristics can be selected, providing information on potential parents to be used in breeding programs (OHASHI et al., 2010). According to Lima et al. (2018), the study of different origins makes it possible to capture various expressions of the genotype, made possible by the different environmental conditions of the place of occurrence.

\section{CONCLUSION}

The D. nigra seedlings from Linhares (ES) show better results of growth and dry mass production.

It is recommended a dose of $7.46 \mathrm{~kg} \mathrm{~m}^{-3}$ of controlled release fertilizer for seedlings from Linhares (ES) and a dose of $5.99 \mathrm{~kg} \mathrm{~m}^{-3}$ for those coming from Viçosa (MG), aiming at maximizing the growth of seedling production of D. nigra.

The increasing doses of controlled release fertilizer allow greater accumulation of $\mathrm{P}$ in the aerial part of D. nigra seedlings.

\section{ACKNOWLEDGMENTS}

This study was financid in part by the Coordernação de Aperfeiçoamento de Pessoal de Nível Superior Brasil (CAPES)- Finance Code 001; the Espírito Santo Research and Innovation Support Foundation (FAPES) and the Espírito Santo State Secretariat for Agriculture, Supply, Aquaculture and Fisheries (SEAG).

\section{REFERENCES}

BRASIL. Ministério da Agricultura, Pecuária e Abastecimento. 2009. Disponível em: $<$ http://www.agricultura.gov.br/assuntos/insumos-agropecuarios/arquivos-publicacoes insumos/2946_regras_analise_sementes.pdf />. Acesso em: $10 \mathrm{dez} .2017$.

BRASIL. MINISTÉRIO DO MEIO AMBIENTE. Acordo de Paris. Disponível em: <http://www.mma.gov.br/clima/convencao-das-nacoes-unidas/acordo-de-paris>. Acesso em: 19 jun 2018.

CARLOS, L.; VENTURIN, N.; VENTURIN, R. P.; ALVES, J. M.; SILVA, P. O. Liming and Phosphating in Dalbergia nigra (Vell.) Allemão ex Benth. Seedlings. Floresta e Ambiente, Seropédica, v. 25, n. 4, p. 1 - 10, 2018.

CARVALHO, P. E. R. Espécies arbóreas brasileiras. Colombo: Embrapa, 2003, 1039 p.

DIAS, L. P. R.; GATIBONI, L. C.; BRUNETTO, G.; ARRUDA, B.; COSTA, M. M. Distribuição e morfologia do sistema radicular de Eucalyptus dunnii em resposta à aplicação de fósforo. Revista de Ciências Agroveterinárias, Lages, v. 16, n. 3, p. 203 - 213, 2017.

DUTRA, T. R.; MASSAD, M. D.; SARMENTO, M. F. Q. Fertilizante de liberação lenta no crescimento e qualidade de mudas de canafístula (Peltophorum dubium (Spreng.) Taub.). Floresta, Curitiba, v. 46, n. 4, p. 491 498, 2016.

FERREIRA, D. F. Sisvar: a guide for its bootstrap procedures in multiple comparisons. Ciência e Agrotecnologia, Lavras, v. 38, n. 2, p. 109 - 112, 2014.

GOMES, J. M.; PAIVA, H. N. Viveiros florestais: propagação sexuada. Editora UFV - Viçosa, MG. Série didática, 2011, 116p.

GONÇALVES, E. D. O.; PAIVA, H. N. D.; NEVES, J. C. L.; KLIPPEL, V. H.; CALDEIRA, M. V. W. Growth of Jacaranda-da-Bahia (Dalbergia nigra ((Vell.) Fr. All. ex Benth)) under different levels of NPK. Cerne, Lavras, v. 20, n. 3, p. 493 -500, 2014.

IRFAN, S. A.; RAZALI, R.; KUSHAARI, K.; MANSOR, N.; AZEEM, B.; VERSYPT, A. N. F. A review of mathematical modeling and simulation of controlled-release fertilizers. Journal of Controlled Release, Stillwater, v. 271, n. 10, p. 45 - 54, 2018.

KOPPEN, W. Climatologia: com um estudio de los climas de la tierra. Buenos Aires: Fondo de Cultura Economica, 1948, 495 p. 
LARCHER, W. Ecofisiologia vegetal. São Carlos: RIMA Artes e Textos, 2006, 532 p.

LIMA, J. S. S.; SILVA, S. A.; OLIVEIRA, R. B.; CECÍLIO, R. A.; XAVIER, A. C. Variabilidade temporal da precipitação mensal em Alegre - ES. Revista Ciência Agronômica, Fortaleza, v. 39, n. 02, p. 327 - $332,2008$.

LIMA, C. C.; OHASHI, S. T.; SILVEIRA, A. S. Efeito de diferentes concentrações de AIB e procedências geográficas no enraizamento de estacas de paricá. Ciência Florestal, Santa Maria, v. 28, n. 3, p. 1282 - 1292 , 2018.

MENEGATTI, R. D., GUOLlO, K., NAVROSKI, M. C., VARGAS, O. F. Fertilizante de liberação lenta no desenvolvimento inicial de Aspidosperma parvifolium A. DC. Scientia Agraria Paranaensis, Cascavel, v. 16, n. 1, p. 45 - 49, 2017.

NAVROSKI, M. C.; TONETT, E. L.; MAZZO, M. V.; FRIGOTTO, T.; PEREIRA, M. O.; GALVANI, L. V. Procedência e adubação no crescimento inicial de mudas de cedro. Pesquisa florestal brasileira, Colombo, v. 36, n. 85, p. 17-24, 2016.

OHASHI, S. T.; YARED, J. A. G.; NETO, J. T. F. Variabilidade entre procedências de paricá Schizolobium parahyba var amazonicum (Huber ex Ducke) Barneby plantadas no município de Colares-Pará. Acta Amazônica, Manaus, v. 40, n. 1, p. 81 - 88, 2010.

RESENDE, L. C.; RIBEIRO, R. A.; LOVATO, M. B. Diversity and genetic connectivity among populations of a threatened tree (Dalbergia nigra) in a recently fragmented landscape of the Brazilian Atlantic Forest. Genetica, Bowling Green, v. 139, n. 9, p. 1159 - 1168, 2011.

ROSA, T. L. M.; JORDAIM, R. B.; ALEXANDRE, R. S.; ARAÚJO, C. P.; GONÇALVES, F. G.; LOPES, J. C. Controlled release fertilizer in the growth of Moringa oleifera LAM. seedlings. Floresta, Curitiba, v. 48, n. 3, p. $303-310,2018$.

ROSSA, Ü. B.; ANGELO, A. C.; WESTPHALEN, D. J.; DE OLIVEIRA, F. E. M.; DA SILVA, F. F.; DE ARAUJO, J. C. Fertilizante de liberação lenta no desenvolvimento de mudas de Anadenanthera peregrina (L.) Speg.(angico-vermelho) e Schinus terebinthifolius Raddi (aroeiravermelha). Ciência Florestal, Santa Maria, v. 25, n. 4, p. 841 - 852, 2015.

SENA J. S.; TUCCI C. A. F.; LIMA, H. N.; HARA, F. A. S. Efeito da calagem e da correção dos teores de Ca e $\mathrm{Mg}$ no solo sobre o crescimento de mudas de angelim pedra (Dinizia excelsa Ducke). Acta amazonica, Manaus, v. 40, n. 2 , p. $309-318,2010$.

SERRANO, L. A. L.; MARINATO, F. A.; MAGIERO, M.; STURM, G. M. Produção de mudas de pimenteirado-reino em substrato comercial fertilizado com adubo de liberação lenta. Ceres, Viçosa, v. 59, n. 4, p. 512 - 517 , 2012.

SILVA, F. C. D. A. S. Manual de análises químicas de solos, plantas e fertilizantes. Brasília, DF: Embrapa Informação Tecnológica, 2 ed. 2009. 627 p.

TAVARES, L. C.; TUNES, L. M.; BRUNES, A. P.; FONSECA, D. Â. R.; RUFINO, C. A.; BARROS, A. C. S. A. Potássio via recobrimento de sementes de soja: efeitos na qualidade fisiológica e no rendimento. Ciência Rural, Santa Maria, v. 43, n. 7, p. 1196 - 1202, 2013.

ZARUMA, D. U. G.; CANUTO, D. S. O.; PUPIN, S.; CAMBUIM, J.; SILVA, A. M.; MORI, E. S.; SEBBENN, A. M.; MORAES, M. L. T. Variabilidade genética em procedências e progênies de Dipteryx alata vogel para Fns de conservação genética e produção de sementes. Scientia Forestalis, Piracicaba, v. 43, n. 107, p. 609 - 615, 2015. 